\title{
Effect of copper and thiomolybdates on bovine theca cell differentiation in vitro
}

\author{
N R Kendall ${ }^{1,2}$, P Marsters ${ }^{1}$, L Guo ${ }^{1}$, R J Scaramuzzi ${ }^{2}$ \\ and B K Campbell ${ }^{\mathbf{1}}$ \\ ${ }^{1}$ Division of Obstetrics and Gynaecology, School of Human Development, Queen's Medical Centre, Nottingham NG7 2UH, UK \\ ${ }^{2}$ Department of Veterinary Basic Sciences, Royal Veterinary College, Royal College Street, London NW1 OTU, UK \\ (Requests for offprints should be addressed to N R Kendall at the School of Human Development, Queen's Medical Centre; \\ Email: Nigel.Kendall@Nottingham.ac.uk)
}

\begin{abstract}
Subfertility that will respond to appropriate copper supplementation is a widespread problem in the national dairy herd. The aims of this study were to determine the effect of copper and/or copper chelating thiomolybdates on LH-induced differentiation by looking at the effects on androgen production, steroidogenic enzymes (cytochrome P450 17a-hydroxylase and cytochrome P450 side-chain cleavage) and lysyl oxidase mRNA expression in cultured theca cells maintained under serum-free conditions.

The effect of thiomolybdates and copper on LH differentiation was investigated by supplementing (ammonium) tetrathiomolybdate to optimum theca cell culture media at 0-100 $\mu \mathrm{g} / \mathrm{ml}$, copper (chloride) at equimolar concentrations $(0-51.6 \mu \mathrm{g} / \mathrm{ml})$ or equimolar combinations of both media. Lysyl oxidase mRNA expression was investigated with semi-quantitative RT-PCR, whilst expression of cytochrome P450 17 $\alpha$-hydroxylase and cytochrome P450 side-chain cleavage mRNA was examined using real time PCR. Both PCRs used bovine specific primers and cell lysates obtained from bovine theca cells cultured for 6 days and in the presence or absence of the $100 \mu \mathrm{g} / \mathrm{ml}$ dose of thiomolybdate and equimolar copper thiomolybdate.

Thiomolybdate depressed androstenedione production in a dose-dependent manner at doses greater than $1 \mu \mathrm{g} / \mathrm{ml}$
\end{abstract}

at $96 \mathrm{~h}(P<0 \cdot 05)$; doses above $20 \mu \mathrm{g} / \mathrm{ml}$ were all greatly reduced at all time points and at $192 \mathrm{~h}$ when related to numbers of cells $(P<0 \cdot 001)$. Copper alone had no effect at physiological doses, but the use of the equimolar copper thiomolybdate reversed the effect of tetrathiomolybdates on androstenedione production at the $20 \mu \mathrm{g} / \mathrm{ml}$ dose. Thiomolybdate supplementation, with and without copper, had no significant effect on the level of lysyl oxidase or cytochrome $\mathrm{P} 450$ side-chain cleavage expression. However, cytochrome P450 17 $\alpha$-hydroxylase expression was significantly increased $(P<0 \cdot 05)$ by tetrathiomolybdate, possibly due to a local regulatory system.

In conclusion, these results demonstrate that thiomolybdates can prevent $\mathrm{LH}$-induced differentiation of bovine theca cells in vitro and that these effects can be ameliorated by copper supplementation. Our results also indicate that it is unlikely that the effects of thiomolybdate are mediated at the transcriptional level and further work is required to determine if thiomolybdate exerts its effects through post-translation processing or some other unrelated mechanism. Overall, these data support the hypothesis that copper responsive subfertility results from perturbation of the normal pattern of ovarian steroidogenesis.

Journal of Endocrinology (2006) 189, 455-463

\section{Introduction}

The declining fertility of the national dairy herd is a major problem in the United Kingdom (Royal et al. 2000). Although subfertility is a multifactoral problem, a considerable proportion of animals have been shown to respond to appropriate copper supplementation (Black \& French 2000, Kendall et al. 2001). Under field conditions, most copper responsive conditions (conditions which strictly are not primarily a copper deficiency but are alleviated by appropriate copper supplementation) are actually induced by molybdenum, which reacts with sulphur in the rumen to form thiomolybdates, which in turn bind copper with high affinity (Dick et al. 1975).

Molybdenum-induced copper depletion has been reported to reduce fertility with associated reduced conception rates, anovulation, anoestrus, decreased basal luteinising hormone (LH) levels, reduced peak surge of $\mathrm{LH}$ and a reduction in the number and frequency of $\mathrm{LH}$ pulses (Phillippo et al. 1987). Du Plessis et al. (1999a) have also shown that behavioural anoestrus occurs relatively quickly, within 6 weeks, in sheep fed a high molybdenum 
and sulphur diet, with true anoestrus occurring after a much longer supplementation time in the trial. Du Plessis et al. (1999b) also showed that ovaries were reduced in size and have a decreased response to a follicle-stimulating hormone (FSH)-induced superovulation regimen in the molybdenum and sulphur supplemented groups. Whilst molybdenum-induced copper depletion may also have central effects via the hypothalamus-pituitary axis on LH secretion, many of the above 'symptoms' are consistent with reduced ovarian oestradiol secretion. The absence of oestrus in animals with copper responsive subfertility could be attributed either to attenuation of the preovulatory oestradiol surge that induces oestrous behaviour and the LH surge or to perturbation of the mechanisms within the central nervous system that result in the behavioural response to this endocrine stimulus (Alexander et al. 1980). Moffor and Rodway (1991) investigated the effect of intravenous administration of tetrathiomolybdate to lambs but found no effect of this treatment on either pulsatile LH or surge release of LH in response to gonadotrophin-releasing hormone or oestradiol challenge. These data suggest that copper responsive subfertility is unlikely to act centrally. Williams (2004) has shown that feeding differing amounts of copper, sulphur, iron and molybdenum alters the amount of copper and molybdenum within the ovary. Increasing the amount of molybdenum fed significantly increased the molybdenum and copper content of the ovary. Although only molybdenum and not thiomolybdate was actually measured, it is likely that a large proportion of the molybdenum is in the form of thiomolybdates (Williams 2004).

We have previously reported (Kendall et al. 2003) that thiomolybdates depressed the FSH-induced differentiation of bovine granulosa cells cultured in a serum-free system for $192 \mathrm{~h}$. This was observed as a reduction in oestradiol production and an alteration in cellular morphology with the loss of the characteristic clumping seen in granulosa cells cultured under serum-free conditions (Gutierrez et al. 1997a, 1997b). An ameliorating effect of copper on thiomolybdate doses was also reported, as was expression of lysyl oxidase mRNA occurring in granulosa cells, both freshly isolated and throughout $192 \mathrm{~h}$ of culture.

Differential expression of the copper-containing enzyme lysyl oxidase was reported by Slee et al. (2001) whilst investigating the genes associated with gonadotrophininduced ovarian somatic cell differentiation in rodents. Lysyl oxidase is essential for the stabilisation of the extracellular matrix (ECM) as it is the enzyme responsible for the cross linking of collagen and elastin monomers. Its action is via the oxidative deamination of peptidyl lysyl groups and the activity has been shown to be linked to increased copper intake (Rucker et al. 1998). Thiomolybdates have also previously been shown to affect lysyl oxidase and subsequent collagen and elastin formation, often observed as symptoms of clinical copper deficiency which include cardiac problems, bone weakness and joint abnormalities (Underwood 1981). The ECM is also considered as an active regulator of cell migration, division, differentiation, death and anchorage with significant and dramatic changes in the remodelling of the extracellular matrix occurring during ovarian follicle development (Rodgers et al. 1998). Collagen type IV, laminin and fibronectin are thought to be present in lamina-like material in the theca matrix and this basal lamina seems to be constantly remodelled as the follicle matures (Rodgers et al. 1999).

Although we have previously shown the effect of thiomolybdates on granulosa cells (Kendall et al. 2003), it is also possible that thiomolybdates have effects on other steroidogenic somatic cells. The theca cells are responsible for the secretion of androgens, which are in turn used as the substrate for oestradiol production by granulosa cells (Baird \& McNeilly 1981). Theca cells secrete androstenedione as their main steroidal product (McNatty et al. 1984). Therefore, a depression in androgen production may become a limiting factor in the secretion of oestrogens and may lead to a depression in ovarian oestrogen production contributing to the symptoms of copper responsive subfertility.

Our hypothesis is that the effects of thiomolybdateinduced copper deficiency on fertility are mediated by perturbation of gonadotrophin-induced steroid production by the somatic cells of the preovulatory follicle. In the present study, we aim to determine whether copper and thiomolybdate supplementation effects androgen production, steroidogenic enzyme and lysyl oxidase mRNA expression by cultured theca cells maintained under serum-free conditions.

\section{Materials and Methods}

\section{Effects of thiomolybdates and copper on cultured theca cells}

Unless otherwise stated all reagents were purchased from Sigma-Aldrich. Bovine ovaries were obtained from a commercial abattoir. Follicles between 2 and $5 \mathrm{~mm}$ in diameter were dissected from a number of ovaries to negate any individual animal effects, and theca cells were isolated using the ovine tissue procedure of Campbell et al. (1998) adapted for use with bovine tissue. Briefly, the dissected follicles were hemisected in Dulbecco's phosphate-buffered saline without calcium and magnesium $\left(\mathrm{dPBS}^{-}\right)$, the granulosa cells were removed by repeated flushing through the barrel of a $1 \mathrm{ml}$ syringe and the theca shells were dispersed by incubation with $10 \mathrm{ml}$ of an enzyme cocktail consisting of $5 \mathrm{mg} / \mathrm{ml}$ collagenase II, $1 \mathrm{mg} / \mathrm{ml}$ hyaluronidase, $1 \mathrm{mg} / \mathrm{ml}$ protease, $0.2 \mathrm{mg} / \mathrm{ml}$ deoxyribonuclease I, and $10 \mu \mathrm{l} / \mathrm{ml}$ fetal calf serum (FCS) (Invitrogen) in $\mathrm{dPBS}^{-}$(Campbell et al. 1998). Dispersion was halted by the addition of $2 \mathrm{ml} \mathrm{FCS}$ and the cells were washed twice in culture media before resuspension and 
counting using a trypan blue viability stain. Theca cell viability is normally greater than $95 \%$ and cells were plated at a density of 75000 viable cells/well in a 96-well flat bottom plate (Nunclon; Nunc, Roskilde, Denmark) with $250 \mu$ l theca culture medium (DMEM:Hams F12 with sodium bicarbonate and $15 \mathrm{mM}$ HEPES $+1 \mathrm{mg} / \mathrm{ml}$ BSA, Penstrep $(100 \mathrm{U} / \mathrm{ml}$ penicillin, $0.1 \mathrm{mg} / \mathrm{ml}$ streptomycin), $0.365 \mathrm{mg} / \mathrm{ml}$ L-glutamine, $5 \mu \mathrm{g} / \mathrm{ml}$ transferrin (Calbiochem, Nottingham, Notts, UK), $0 \cdot 1 \mu \mathrm{g} / \mathrm{ml}$ selenium) with optimum doses of $10 \mathrm{ng} / \mathrm{ml}$ insulin, $1 \mathrm{ng} / \mathrm{ml}$ LR3-insulin-like growth factor-I (LR3-IGF-I) (Bachem, St Helens, Merseyside, UK) and $0 \cdot 1 \mathrm{ng} / \mathrm{ml}$ ovine LH (NIDDK-oLH-S26, bioactivity $2 \cdot 3 \mathrm{IU} / \mathrm{mg}$ ) to induce theca cell differentiation (Campbell et al. 1998). To four wells per replicate plate (4 plates), treatments were applied as follows: ammonium tetrathiomolybdate $\left(\left(\mathrm{NH}_{4}\right)_{2} \mathrm{MoS}_{4}\right)(\mathrm{TTM})$ was added to the media at concentrations of $0,0 \cdot 1,1,5,20$ and $100 \mu \mathrm{g} / \mathrm{ml}$ (termed TTM-0, TTM-0-1, TTM-1, TTM-5, TTM-20, TTM-100), tissue culture grade copper chloride hydrate $\left(\mathrm{CuCl}_{2}\right)(\mathrm{Cu})$ was added at equimolar equivalents with concentrations of $0,0.0516,0.516,2 \cdot 08,10.32$ and $51.6 \mu \mathrm{g} / \mathrm{ml}$ (termed $\mathrm{Cu}-0, \mathrm{Cu}-0 \cdot 1, \mathrm{Cu}-1, \mathrm{Cu}-5, \mathrm{Cu}-20, \mathrm{Cu}-100)$ and equimolar concentrations of the two compounds (CuTTM) mixed to form CuTTM-0, CuTTM-0·1, CuTTM-1, CuTTM-5, CuTTM-20, CuTTM-100 treatments. The cells were cultured for $144 \mathrm{~h}$ with $175 \mu \mathrm{l}(70 \%)$ media changed every $48 \mathrm{~h}$ for fresh treatment media. Removed media were retained, and stored at $-20{ }^{\circ} \mathrm{C}$ for subsequent analysis of androstenedione concentrations. Cell numbers were estimated using the neutral red cell viability stain at the end of the culture (144 h) (Campbell et al. 1996).

\section{Androstenedione assay}

Androstenedione concentrations were assayed using a previously validated double antibody radioimmunoassay (Campbell et al. 1990). The sensitivity of the assay was $39 \mathrm{pg} / \mathrm{ml}$ and the intra- and interassay coefficients of variation were both less than 15\%. Androstenedione concentrations were expressed as total production for all time points with concentrations at the $144 \mathrm{~h}$ time point also being expressed on a 'cell number' basis. All androstenedione concentrations were naturally logged to obtain a normal distribution prior to statistical analysis

Expression of $m R N A$ for lysyl oxidase, cytochrome P450 side-chain cleavage and cytochrome P450 17a-hydroxylase in theca cells

Theca cells were isolated as described above and cells were plated at a density of $5 \times 10^{5}$ viable cells/well in a 24 -well flat bottom plate (Nunclon) with $1 \mathrm{ml}$ theca culture medium with optimum insulin, LR3-IGF-I and oLH of 10,1 , and $0 \cdot 1 \mathrm{ng} / \mathrm{ml}$ respectively to induce theca cell differentiation (Campbell et al. 1998). Media (800 $\mu \mathrm{l}, 80 \%$ of well volume) were changed every $48 \mathrm{~h}$ where appropriate. The effect of thiomolybdate on lysyl oxidase, cytochrome P450 17 $\alpha$-hydroxylase and cytochrome P450 side-chain cleavage expression of theca cells was determined by the addition of ammonium tetrathiomolybdate $\left(\left(\mathrm{NH}_{4}\right)_{2} \mathrm{MoS}_{4}\right)$ (Sigma-Aldrich) at concentrations of $100 \mu \mathrm{g} / \mathrm{ml}$ (TTM-100) to the media, equimolar concentrations of copper were added for a copper thiomolybdate treatment (CuTTM-100) and no supplement was added to give a no treatment control (NT). These treatments were applied to three replicate cultures. At each time point $(16,24,48,96,144$ and $192 \mathrm{~h})$, after removal of culture media (retained and stored at $-20{ }^{\circ} \mathrm{C}$ for subsequent androstenedione assay), cells from each well were harvested into $150 \mu \mathrm{l}$ RTL lysis buffer (RNeasy; Qiagen) containing $1 \% \beta$-mercaptoethanol and retained at $-20{ }^{\circ} \mathrm{C}$ for subsequent analysis. Total RNA was isolated from the lysed cell samples using the RNeasy mini kit (Qiagen) and protocol. First strand cDNA synthesis was performed using iT 1st strand synthesis kit (ABgene, Epsom, Surrey, UK). As analysis is semi-quantitative, random hexamers (Promega) were used to prime the cDNA strand as an $18 \mathrm{~S}$ internal standard (QuantumRNA 18S rRNA Universal Internal Standard; Ambion, Huntingdon, UK) was used in all cases. All PCR amplifications were performed using bovine-specific cDNA distinguishing primers.

Semi-quantitative lysyl oxidase mRNA expression analysis was performed by conventional PCR and utilised a primer set targeting a region spanning the 3rd (sense, $5^{\prime}$-TTCCTACCAAGTCGACCAAGA- $3^{\prime}$ ) to the 6th exon (antisense, $5^{\prime}$-TGCATAAGCGTGATGTCCTG-3') and deriving a 399 base pair amplicon product that was beyond optimal real-time size parameters. Both the cytochrome P450 17a-hydroxylase and cytochrome P450 side-chain cleavage expression analyses utilised real-time PCR technology and were performed on a Quantica detection system (TECHNE; Duxford, Cambridgeshire, UK) with QuantiTect SYBR Green (Qiagen) fluorescent label. The cytochrome P450 17a-hydroxylase reactions utilised the sense primer 5'-CAAGGATGGCAACCTG AAG $-3^{\prime}$ and the antisense primer 5'-CAGAGAGAGAG GCTCGGACA-3' which amplified a 115 base pair product, while the cytochrome $\mathrm{P} 450$ side-chain cleavage reaction used the sense primer $5^{\prime}$-TTCGCCACATCGA GAACTT- $3^{\prime}$ and the antisense primer $5^{\prime}$-CCTCGAA CTTGAAGAGATGG-3' and derived a 117 base pair amplicon. In order to measure reaction efficiency, a standard curve was generated for each gene using standards of $10^{4}, 10^{3}, 10^{2}, 10^{1}$, and $1 \mathrm{pg}$ cDNA. Each reaction was run in duplicate and the mean log cDNA concentrations versus cycle threshold were plotted. The PCR products were electrophoresed on $2 \%$ agarose gels containing ethidium bromide, and visualised under UV light. Subsequent analysis was by laser densitometry. PCR products from parallel gels were excised and purified using QIAquick Gel extraction kit (Qiagen). Product identities 


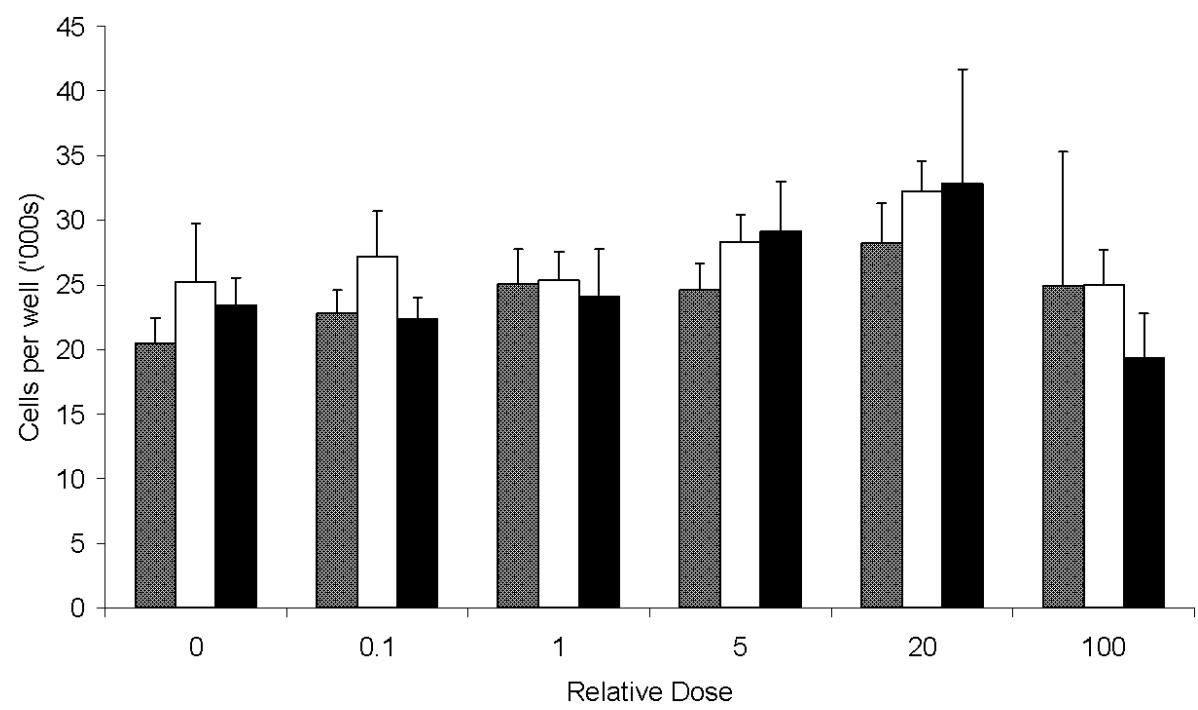

Figure 1 The mean ( \pm S.E.M.) numbers of theca cells cultured under optimum serum-free conditions at the end of culture at $144 \mathrm{~h}$ with $\mathrm{Cu}$ added to the media (shaded bars), CuTTM added to the media (open bars) and TTM added to the media (solid bars). The relative doses are equimolar concentrations equivalent to tetrathiomolybdate in $\mu \mathrm{g} / \mathrm{ml}$. No data points are significantly different $(P>0 \cdot 05)$.

generated by each primer set were subsequently confirmed by sequencing.

\section{Statistical analysis}

Statistical analysis was carried out with SPSS (Chicago, IL, USA) using a univariate general linear model (GLM) for single time point analysis and repeated measures GLM for multi-time point analysis. The analysis was blocked by individual culture plate. Individual group comparisons were carried out using the Bonferroni method.

\section{Results}

\section{Cellular morphology and cell number}

The theca cells all assumed the characteristic dispersed monolayer of flattened fibroblastic cells observed in this serum-free system (Campbell et al. 1998). There were no apparent alterations in cellular morphology between the treatment groups. Cell numbers are shown in Fig. 1 and show no significant effect of any treatment or dose on the numbers of cells present after $144 \mathrm{~h}$ of culture.

\section{Androstenedione production}

Theca cells from the small antral follicles cultured serumfree in the presence of optimal doses of LH, insulin and
IGF-I, shown previously to induce cellular differentiation (Campbell et al. 1998), displayed the expected induction of androstenedione production with increasing time in culture, with maximal levels after $144 \mathrm{~h}$ (Fig. 2). The $0 \cdot 1$ and 1 doses of TTM had little effect on this induction profile, whilst the TTM-5 dose showed a significant reduction $(P<0 \cdot 01)$ at $96 \mathrm{~h}$ compared with the $0,0 \cdot 1$ and 1 doses, and at $144 \mathrm{~h}$ compared with the TTM-1 dose $(P<0 \cdot 01)$. Androstenedione was further significantly reduced at the TTM-20 dose $(P<0 \cdot 001)$ and was virtually undetectable at the TTM-100 dose $(P<0 \cdot 001)$ for all three time points compared with the $0,0 \cdot 1$ and 1 doses.

Copper alone had no significant effect on androstenedione production at all time points at any dose apart from the $\mathrm{Cu}-100$ dose $(P<0 \cdot 001)$ and the $\mathrm{Cu}-20$ dose which was higher than the $\mathrm{Cu}-0 \cdot 1$ dose at $96 \mathrm{~h}(P<0 \cdot 05)$ (Fig. 2b). Similarly, when related to cell number at $144 \mathrm{~h}$ (Fig. 3) only the Cu-100 dose had any effect on androstenedione production $(P<0 \cdot 001)$.

The effect of combining $\mathrm{Cu}$ and TTM on androstenedione production is shown in Fig. 2c. These results show no significant differences in androstenedione production for the $0,0 \cdot 1,1,5$ and 20 doses, apart from the CuTTM-20 having increased androstenedione production over the CuTTM-0 dose at $96 \mathrm{~h}(P<0 \cdot 05)$. However, the CuTTM-100 dose significantly depressed androstenedione production $(P<0 \cdot 001)$ at all time points without (Fig. 2c) and with (Fig. 3) correction for cell number.

Figure 2 The mean ( \pm S.E.M.) androstenedione production $(\mathrm{pg} / \mathrm{ml})$ of the theca cells cultured under optimum serum-free conditions with (a) TTM added to the media, (b) Cu added to the media, and (c) CuTTM added to the media for 48 (shaded bars), 96 (open bars) and 144 (solid bars) hours. The relative doses are equimolar concentrations equivalent to tetrathiomolybdate in $\mu \mathrm{g} / \mathrm{ml}$. Within the same time (but across all three treatments), data points not sharing a common letter are significantly different $(P<0 \cdot 05)$. 

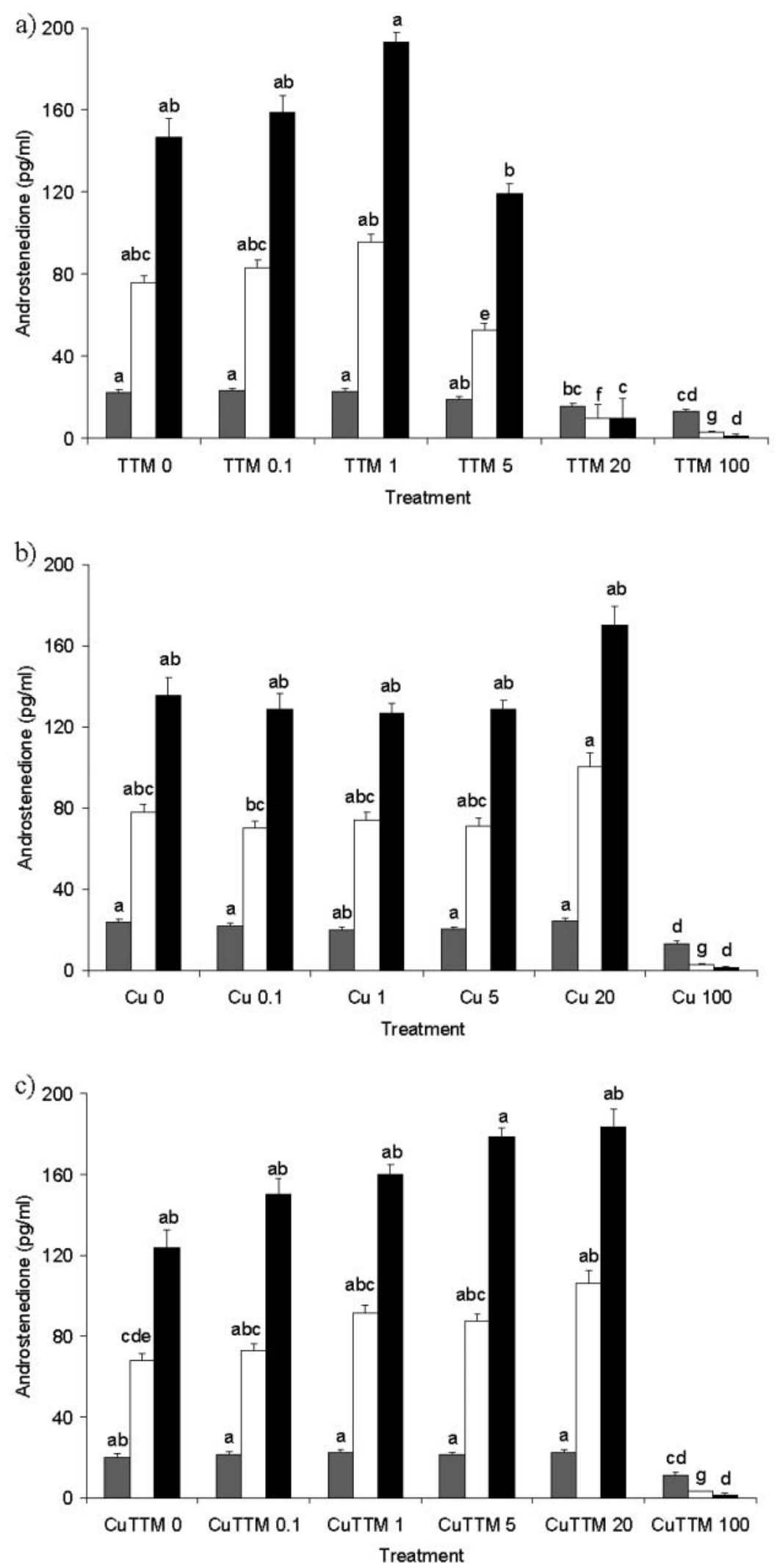


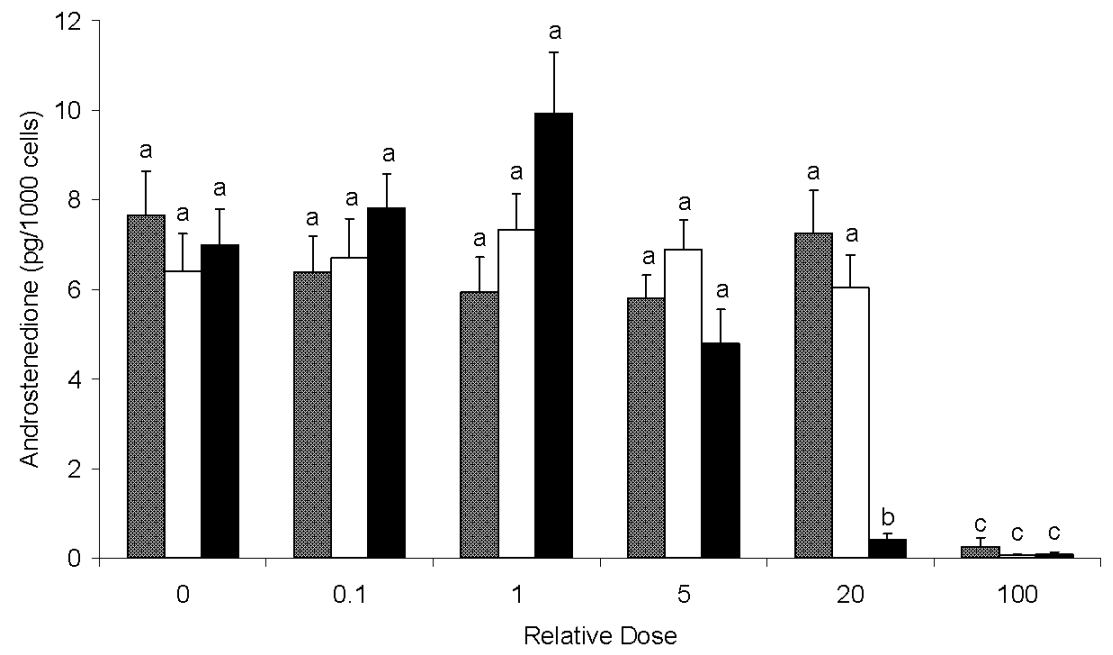

Figure 3 The mean ( \pm S.E.M.) androstenedione production on a cell number basis (pg/1000 cells) after $144 \mathrm{~h}$ of serum-free culture under optimum conditions with $\mathrm{Cu}$ added to the media (shaded bars), CuTTM added to the media (open bars) and TTM added to the media (solid bars). The relative doses are equimolar concentrations equivalent to tetrathiomolybdate in $\mu \mathrm{g} / \mathrm{ml}$. Data points not sharing a common letter are significantly different $(P<0 \cdot 05)$.

In comparison with TTM alone, the CuTTM treatment prevented the depression observed at the 20 dose $(P<0 \cdot 001)$ across all three time points (Fig. 2a,c). A similar effect was observed when data were expressed in relation to cell number (Fig. 3). Further the TTM-5 dose differed from the CuTTM-5 dose at the $96 \mathrm{~h}(P<0 \cdot 001)$ and $144 \mathrm{~h}$ $(P<0 \cdot 05)$ time points.

Correction of these data for cell number after $144 \mathrm{~h}$ of culture (Fig. 3) had little effect on the overall treatment response, with no significant difference for the $0,0 \cdot 1$ and 1 doses whereas doses of TTM greater than 20 resulted in a marked inhibition in androstenedione production $(P<0 \cdot 001)$.

\section{Lysyl oxidase expression}

Lysyl oxidase (399 bp amplicon) and the $18 \mathrm{~S}$ internal positive control (317 bp amplicon) were expressed across all the time points $(0,16,24,48,96$ and $144 \mathrm{~h})$ of the culture in non-treated controls (data not shown). The effects of thiomolybdate supplementation or thiomolybdate with equimolar copper supplementation (both at 100 dose) on lysyl oxidase expression at $96 \mathrm{~h}$ are shown in Fig. 4. It can be seen that expression of lysyl oxidase mRNA for the TTM-100 dose was not significantly different from either the non-treated or the CuTTM100-treated cells.

Cytochrome P450 17a-hydroxylase and cytochrome P450 side-chain cleavage expression

The relative mRNA expression of the steroidogenic enzymes cytochrome 17 $\alpha$-hydroxylase and cytochrome
P450 side-chain cleavage at $96 \mathrm{~h}$ are shown in Fig. 5. Both TTM and CuTTM had a slight depressive effect on cytochrome $\mathrm{P} 450$ side-chain cleavage $(P=0 \cdot 22)$. Conversely, TTM supplementation significantly $(P<0 \cdot 05)$ up-regulated the cytochrome P450 17 $\alpha$-hydroxylase expression whereas the CuTTM had no effect.

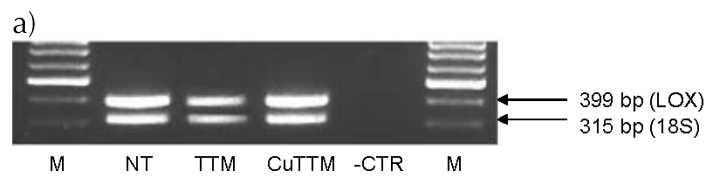

b)

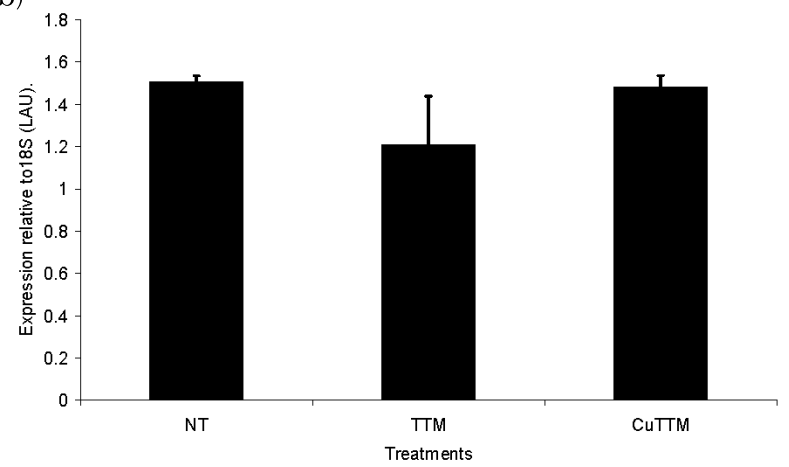

Figure 4 (a) The gel product of the PCR showing lysyl oxidase (LOX; $399 \mathrm{bp}$ ) and $18 \mathrm{~S}$ internal standard (317 bp) amplicons. $\mathrm{M}$, molecular weight marker lane. (b) The mean ( \pm S.E.M.) relative expression of LOX to $18 \mathrm{~S}$ internal standard from theca cells cultured for $96 \mathrm{~h}$ with optimum media (NT), the addition of $100 \mu \mathrm{g} / \mathrm{ml}$ ammonium tetrathiomolybdate (TTM) and the addition of $100 \mu \mathrm{g} / \mathrm{ml}$ ammonium tetrathiomolybdate and equimolar copper chloride (CUTTM). LAU, light arbitary units. 


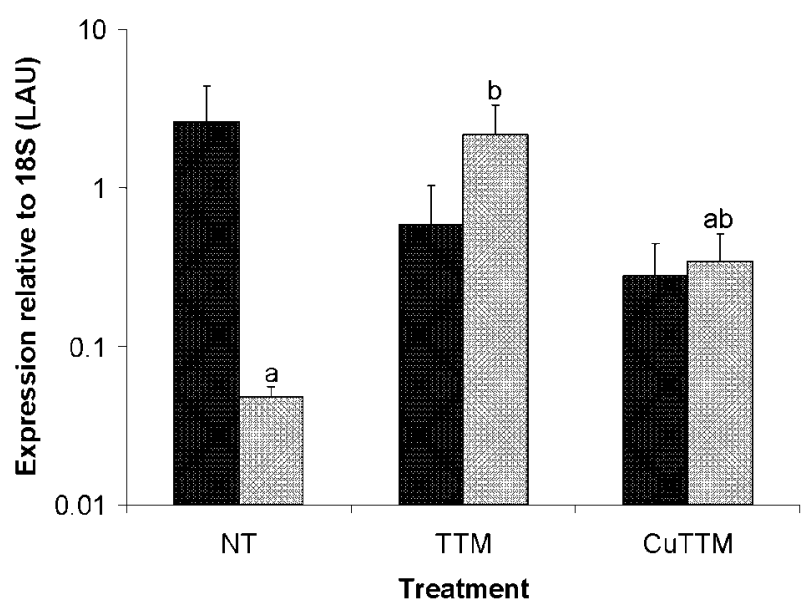

Figure 5 The relative expression of cytochrome P450 side-chain cleavage (solid bars) and cytochrome P450 17 $\alpha$-hydroxylase (shaded bars) after $96 \mathrm{~h}$ of serum-free culture, with no treatment (NT), tetrathiomolybdate at $100 \mu \mathrm{g} / \mathrm{ml}$ dose (TTM) or tetrathiomolybdate at $100 \mu \mathrm{g} / \mathrm{ml}$ dose with equimolar copper (CUTTM). Different letters indicate a significant difference $(P<0 \cdot 05)$ for cytochrome P450 17 -hydroxylase. There was no significant difference between cytochrome P450 side-chain cleavage results. $\mathrm{LAU}$, light arbitary units.

\section{Discussion}

The results within the present experiment show that TTM is able to prevent LH-induced differentiation of bovine theca cells in culture and that copper can ameliorate the effect of TTM on androstenedione production. These depressive effects could not be attributed to changes in mRNA expression for the steroidogenic enzymes cytochrome P450 17a-hydroxylase and cytochrome P450 side-chain cleavage, nor the copper-dependent enzyme lysyl oxidase.

The effects of thiomolybdates in the whole animal have previously been shown to include reduced conception rates, anovulation and anoestrus, which were associated with a decreased release of LH (Phillippo et al. 1987). The pre-ovulatory oestradiol peak is the endocrine signal responsible for induction of both behavioural oestrus and the preovulatory LH surge (Baird \& McNeilly 1981) and the dominant follicle in ruminants is the source of over 96\% of ovarian oestradiol secretion (Baird \& Scaramuzzi 1976). Theca cells do not produce oestradiol directly, but produce androgens that are used as a substrate by granulosa cells in the production of oestradiol (Baird \& McNeilly 1981). It has been estimated that androstenedione represents $82 \%$ of the steroid secreted by the theca cells, testosterone accounting for only 5\% (McNatty et al. 1984). Therefore, a reduction in the production of androstenedione, as we have reported for TTM doses greater than 5 , is likely to limit the production of oestradiol due to substrate limitation. The results of the present study are consistent with an effect of molybdenum-induced copper deficiency on the development of the preovulatory follicle, especially steroid secretion, and would therefore be expected to perturb both behavioural oestrus and ovulation to a varying degree, as has been observed in animals with molybdenum-induced copper responsive subfertility (Phillippo et al. 1987, Du Plessis et al. 1999a, 1999b). Further, it is well established that ovarian oestradiol plays a key role in controlling gamete transport and in priming the uterus for implantation, so that even if ovulation does occur, fertility rates are likely to be impaired if preovulatory oestradiol production is sub-optimal (Hafez 1980). Again, this is one of the key symptoms of copper-responsive subfertility (Du Plessis et al. 1999a) and further studies are required to examine the effects of molybdenum-induced copper deficiency on the pattern of development and steroidogenic capacity of ovulatory follicles in vivo.

Examination of the effects of TTM treatment on expression of two key steroidogenic enzymes that result in androstenedione biosynthesis, cytochrome P450 17ahydroxylase and cytochrome P450 side-chain cleavage seems to preclude the level of mRNA expression as an explanation of the depressive effects of TTM treatment.

Copper may be acting indirectly either through mitochondrial energy (cytochrome $c$ oxidase requires three copper ions) or the cofactors to cytochrome P450 sidechain cleavage, which are ferredoxin and ferredoxin reductase (copper is extensively involved in iron metabolism).

However, cytochrome P450 side-chain cleavage, which is often regarded as the rate limiting step in this steroidogenic pathway (Miller 2002), was only marginally depressed $(P=0.22)$ by exposure to TTM, whereas, conversely, cytochrome P450 17 $\alpha$-hydroxylase expression was markedly up-regulated $(P<0 \cdot 05)$. This unexpected finding raises the interesting possibility that cytochrome P450 17a-hydroxylase expression is under the control of a local regulatory feedback system that has been perturbed by treatment with TTM. Thus, from our results this perturbation is likely to act via low concentrations of the enzyme product i.e. androstenedione. More direct experimental analysis is required to investigate this interesting and novel observation in more detail. Further work is also required to determine whether TTM treatment acts to depress LH-stimulated thecal cell androgen production by affecting the enzymatic activity of cytochrome P450 $17 \alpha$-hydroxylase and cytochrome P450 side-chain cleavage, rather than their level of mRNA transcription.

The results of this study also show that mRNA for the copper-dependent enzyme lysyl oxidase is expressed by freshly isolated and cultured theca cells. This is not surprising as dramatic changes and remodelling of the extracellular matrix occur during ovarian follicle development (Rodgers et al. 1998). The ECM is also considered as an active regulator of cell migration, division, differentiation, death and anchorage. Collagen type IV, laminin 
and fibronectin have previously been shown to be secreted by cultured granulosa cells (Rodgers et al. 1995, 1996) and are also thought to be present in lamina-like material in the theca matrix (Rodgers et al. 1999). The basal lamina seems to be constantly remodelled as the follicle matures (Rodgers et al. 1999) which may explain a putative role of lysyl oxidase in androstenedione production.

However, in this paper, although we have shown that cultured theca cells express lysyl oxidase and that thiomolybdates depress the steroid production of the cells, thiomolybdates did not affect lysyl oxidase expression to a significant extent. Therefore, these results indicate that it is unlikely that these effects of TTM are mediated by lysyl oxidase at the transcriptional level and further work is required to determine if TTM exerts its effects through lysyl oxidase translation, post-translational processing or some other unrelated mechanism. Harlow et al. (2003) showed that increased androgen ( $5 \alpha$-dihydrotestosterone) increased the level of mRNA expression for lysyl oxidase in rat granulosa cells in a serum-supplemented culture. In the present study, the increased androgen production found for the non-treated cells in comparison with the tetrathiomolybdate (TTM-100)-treated cells was found to have no effect on lysyl oxidase mRNA expression. However, the differences between this work and that of Harlow et al. (2003) may be explained by the use of different cell types (granulosa vs theca), different species (rat vs bovine) and different culture types (serum containing vs serum free). Slee et al. (2001) found no lysyl oxidase mRNA expression in rat theca cells cultured in a serum containing culture, whereas they did find lysyl oxidase expression in rat granulosa cells. The contamination of the serum-free theca cell culture type used in this study with granulosa cells is negligible (approx. 1\%) and would not explain the lysyl oxidase expression found.

In a previous study we have similarly reported that TTM can inhibit FSH-induced oestradiol production by cultured granulosa cells, and that these effects can be ameliorated by co-incubation with copper (Kendall et al. 2003). The fact that TTM has similar effects in both granulosa and theca cells suggests that copper responsive subfertility may be mediated through effects on both these cell types, but their relative importance remains unclear. However, an interesting difference between the cell types observed in these studies was an apparent increase in sensitivity to copper for theca cells. In theca cells in the present paper a copper dose of $100(51.6 \mu \mathrm{g} / \mathrm{ml})$ was used as the highest dose and had the effect of reducing androstenedione production without affecting the number of cells. However, in granulosa cells (Kendall et al. 2003) a similar copper dose had no apparent effect on cell number, oestradiol production or morphology of the cells and a much higher copper dose of $1000(516 \mu \mathrm{g} / \mathrm{ml})$ was required to elicit these responses. This effect may possibly be due to the inhibition by copper of cytochrome $\mathrm{p} 450$ catalysed reactions. Kim et al. (2002) found a $30 \mu \mathrm{M}$ dose of $\mathrm{CuCl}_{2}$ completely depressed cytochrome P450 activity in an in vitro assay. As the granulosa cell culture has testosterone substrate in the media it therefore relies only on cytochrome P450 aromatase activity, whereas the theca cell culture relies on de novo synthesis of steroids and therefore many cytochrome P450 catalysts.

An argument often used in cell culture studies is that effects are observed at non-physiological, often pharmacological doses. In the granulosa cell studies (Kendall et al. 2003) we calculated the expected physiological doses working from published concentrations of copper and molybdenum in blood and came to the conclusion that the physiological range for thiomolybdate and copper were equivalent to our doses of TTM- $0 \cdot 14$ to TTM-8 1 and $\mathrm{Cu}-0.31$ to $\mathrm{Cu}-0.77$ respectively. This means that the differential effects seen in this paper of a small but significant decrease at a dose of TTM- 5 , with a highly significant decrease for the TTM-20 dose are at the higher end of the calculated physiological dose and can therefore be expected to cause similar effects in vivo.

In conclusion, the results within the present experiment show that TTM is able to prevent LH-induced differentiation of bovine theca cells in culture and that copper can ameliorate the effect of TTM on androstenedione production. These depressive effects did not appear to be mediated by any fall in mRNA expression for the steroidogenic enzymes cytochrome P450 17 $\alpha$-hydroxylase and cytochrome P450 side-chain cleavage. Further, the experiments demonstrated that although the copperdependent enzyme, lysyl oxidase, is expressed by theca cells, TTM does not exert its effect by modulating the level of lysyl oxidase mRNA expression. Overall, these data support the hypothesis that the effect of TTM on fertility may be mediated via perturbation of the normal pattern of ovarian steroidogenesis.

\section{Acknowledgements}

The authors wish to thank the National Institute of Arthritis, Diabetes and Digestive and Kidney Diseases (Torrence, CA, USA) for the LH preparation, Anne Kelly at the University of Glasgow for androstenedione radiolabel and BBSRC for funding Dr Kendall. The technical assistance of $\mathrm{Mr}$ Ioannis Sfontouris and Mrs Catherine Pincott-Allen is much appreciated. The authors declare that there is no conflict of interest that would prejudice the impartiality of this scientific work.

\section{References}

Alexander G, Signoret JP \& Hafez ESE 1980 Sexual, maternal and neonatal behavior. In Reproduction in Farm Animals, 4th edn, pp 304-334. Ed ESE Hafez. Philadelphia, PA, USA: Lea and Febiger. 
Baird DT \& Scaramuzzi RJ 1976 The source of ovarian oestradiol and androstenedione in the sheep during the luteal phase. Acta Endocrinologica 83 402-409.

Baird DT \& McNeilly AS 1981 Gonadotrophic control of follicular development and function during the oestrous cycle of the ewe. Journal of Reproduction and Fertility Suppl 30 119-133.

Black DH \& French NP 2000 Copper supplementation and bovine pregnancy rates: three types of supplementation compared in commercial dairy herds. Irish Veterinary Journal 53 213-222.

Campbell BK, Mann GE, McNeilly AS \& Baird DT 1990 The pattern of ovarian inhibin, oestradiol and androstenedione secretion during the oestrous cycle in the ewe. Endocrinology 127 227-235.

Campbell BK, Scaramuzzi RJ \& Webb R 1996 Induction and maintenance of oestradiol and immuno-reactive inhibin production with FSH by ovine granulosa cells cultured in serum free media. Journal of Reproduction and Fertility 106 7-16.

Campbell BK, Baird DT \& Webb R 1998 Effect of dose of LH on androgen production and luteinization of ovine theca cells cultured in a serum-free system. Journal of Reproduction and Fertility 112 69-77.

Dick AT, Dewey DW \& Gawthorne JM 1975 Thiomolybdates and the copper-molybdenum-sulphur interaction in ruminant nutrition. Journal of Agricultural Science 85 567-568.

Du Plessis SS, Van Niekerk FE \& Coetzer WA 1999a The effect of dietary molybdenum and sulphate on the oestrous cycle and ovulation in ewes after manipulation with exogenous progesterone alone or in combination with FSH and LH. Small Ruminant Research 33 63-69.

Du Plessis SS, Van Niekerk FE \& Coetzer WA $1999 b$ The effect of dietary molybdenum and sulphate on the sexual activity and plasma progesterone concentrations of ewes. Small Ruminant Research $3371-76$.

Gutierrez CG, Campbell BK \& Webb R 1997a Development of a long-term bovine granulosa cell culture system: induction and maintenance of oestradiol production, response to $\mathrm{FSH}$ and morphological characteristics. Biology of Reproduction 56 608-616.

Gutierrez CG, Glazyrin AL, Robertson GW, Campbell BK, Gong JG, Bramley TA \& Webb R $1997 b$ Ultra-structural characteristics of bovine granulosa cells associated with maintenance of oestradiol production in vitro. Molecular and Cellular Endocrinology 134 51-58.

Hafez ESE 1980 Transport and survival of gametes. In Reproduction in Farm Animals, 4th edn, pp 203-225. Ed ESE Hafez. Philadelphia, PA, USA: Lea and Febiger.

Harlow CR, Rae M, Davidson L, Trackman PC \& Hillier SG 2003 Lysyl oxidase gene expression and enzyme activity in the rat ovary: regulation by follicle-stimulating hormone, androgen, and transforming growth factor-beta superfamily members in vitro. Endocrinology 144 154-162.

Kendall NR, Illingworth DV \& Telfer SB 2001 Copper responsive infertility in British cattle: the use of a blood caeruloplasmin to copper ratio in determining a requirement for copper supplementation. In Fertility in the High-Producing Dairy Cow, Occasional Publication No. 26, vol. 2, pp 429-432. Ed MG Diskin. Edinburgh, UK: British Society of Animal Science.

Kendall NR, Marsters P, Scaramuzzi RJ \& Campbell BK 2003 Expression of lysyl oxidase and effect of copper chloride and ammonium tetrathiomolybdate on bovine ovarian follicle granulosa cells cultured in serum-free media. Reproduction 125 657-665.

Kim J-S, Ahn T, Yim S-K \& Yun C-H 2002 Differential effect of copper (II) on the cytochrome P450 enzymes and NADPHcytochrome $\mathrm{P} 450$ reductase: inhibition of cytochrome P450catalysed reactions by copper (II) ion. Biochemistry 41 9438-9447.

McNatty KP, Heath DA, Lun S, Fannin JM, Mc Diarmid JM \& Henderson KM 1984 Steroidogenesis by bovine theca interna in an in vitro perfusion system. Biology of Reproduction 30 143-150.

Miller WL 2002 Androgen biosynthesis from cholesterol to DHEA. Molecular and Cellular Endocrinology 198 7-14.

Moffor FM \& Rodway RG 1991 The effect of tetrathiomolybdate on growth rate and onset of puberty in ewe-lambs. British Veterinary Journal 147 421-431.

Phillippo M, Humphries WR, Atkinson T, Henderson GD \& Garthwaite PH 1987 The effect of dietary molybdenum and iron on copper status, puberty, fertility and oestrous cycles in cattle. Journal of Agricultural Science 109 321-336.

Rodgers HF, Lavranos TC, Vella CA \& Rodgers RJ 1995 Basal lamina and other extracellular matrix produced by bovine granulosa cells in anchorage independent culture. Cell and Tissue Research 282 463-471.

Rodgers HF, Irvine CM, van Wezel IL, Lavranos TC, Luck ML, Sado Y, Ninomiyia Y \& Rodgers RJ 1998 Distribution of the alpha 1 to alpha 6 chains of type IV collagen in the bovine follicles. Biology of Reproduction 59 1334-1341.

Rodgers RJ, Vella CA, Rodgers HF, Scott K \& Lavranos TC 1996 Production of extracellular matrix fibronectin, and steroidogenic enzymes, and growth of bovine granulosa cells in anchorageindependent culture. Reproduction, Fertility and Development 8 249-257.

Rodgers RJ, van Wezel IL, Irving-Rodgers HF, Lavranos TC, Irvine CM \& Krupa M 1999 Roles of extracellular matrix in follicle development. Journal of Reproduction and Fertility Suppl 54 343-352.

Royal MD, Darwash AO, Flint APE, Webb R, Woolliams JA \& Lamming GE 2000 Declining fertility in dairy cattle: changes in traditional and endocrine parameters of fertility. Animal Science 70 487-501.

Rucker RB, Kosonen T, Clegg MS, Mitchell AE, Rucker BR, Urie-Hare JY \& Keen CL 1998 Copper, lysyl oxidase and extracellular matrix protein cross-linking. American Journal of Clinical Nutrition 67 996S-1002S.

Slee RB, Hillier SG, Largue P, Harlow CR, Miele G \& Clinton M 2001 Differentiation-dependent expression of connective tissue growth factor and lysyl oxidase messenger ribonucleic acids in rat granulosa cells. Endocrinology 142 1082-1089.

Underwood EJ 1981 The Mineral Nutrition of Livestock, 2nd edn, pp 91-108. Oxon: CABI.

Williams CL 2004 The effects of molybdenum, iron and sulphur on copper metabolism and physiology of sheep. PhD Thesis, Harper Adams University College.

Received in final form 2 March 2006

Accepted 14 March 2006

Made available online as an Accepted Preprint 22 March 2006 